\title{
Sociological Conceptualization of the Medicalization of Pregnancy and Childbirth: The Implications in Slovenia
}

\author{
Mirko PROSEN \\ Faculty of Health Sciences, University of Primorska, Slovenia \\ mirko.prosen@fvz.upr.si \\ Marina TAVČAR KRAJNC \\ Department of Sociology, Faculty of Arts, University of Maribor, Slovenia \\ marina.tavcar@um.si
}

The article examines the medicalization of pregnancy and childbirth and the ten-
dency to humanize or demedicalize childbirth. The concept of childbirth dramati-
cally changed in Western countries over the last century. Pregnancy and childbirth
were still considered to be a natural phenomenon at the beginning of the $20^{\text {th }}$
century. In the second half of the $20^{\text {th }}$ century, which coincides with more intense
development of gynaecology and obstetrics and the related technology, pregnancy
and childbirth became the subject of the jurisdiction of medicine. Medicalization in
Peter Conrad's terms is a process by which non-medical problems become defined
as medical, which is also related to the implementation of medical interventions.
A descriptive research method was used to perform a literature review related to
the medicalization of pregnancy and childbirth. In addition to a general overview
of the theme, the review focused on the Slovenian context. Discussions about the
medicalization of pregnancy and childbirth and natural childbirth create ambiva-
lence, since technological advances also help to save lives. The feminist critique
sees the medicalization of pregnancy and childbirth in the function of control over
women's bodies and reproduction. The process of humanization therefore focuses
on woman and her ability to make independent decisions related to pregnancy and
childbirth. Through the literature review, it is indicated that there is a need for
further empirical research to explain more clearly the interweaving of these two
perspectives, especially in Slovenia, where such studies are extremely limited.

Key words: medicalization, pregnancy, childbirth, natural childbirth, feminism, humanism

\section{Introduction}

Childbirth is an important event in every society; biologically, of course, but also culturally and sociologically. This importance reflects wider socio- 
logical values and, through them, everything that society values most: the course of childbirth is inextricably bound to the development of society. In Western societies before the $20^{\text {th }}$ century, childbirth was thought of as a natural event. The course of childbirth was determined by natural forces and medical procedures were not required or, if they were, it was in a small minority of cases. Home delivery was particularly prevalent in rural environments and resulted in a higher percentage of maternal and perinatal deaths (Barker, 1998; Zwelling, 2008). At the end of the $19^{\text {th }}$ and beginning of the $20^{\text {th }}$ century, coinciding with the advancing industrial revolution, obstetrics became increasingly important within medical science. The development and function of the medical profession was based on a biomedical model that presupposed that there was a biophysical explanation that could be objectively defined for every disease. Because of the high rate of mortality among mothers and newborns, the medical profession intervened in both, determining, in effect, that natural processes were risky and even pathological. Classified as such, they were subjected to control and monitoring, which inevitably led to an intensification that could only be implemented within institutions (Zwelling, 2008; Behruzi et al., 2010).

Childbirth in maternity hospitals in Slovenia became common practice after World War II (Borisov, 1995). The midwife's position was taken over by patriarchal and authority based medicine, breastfeeding was replaced by the development of milk formulas (Cahill, 2001; Prosen and Prosen, 2011). Technology took on a larger role in the monitoring of pregnancy and childbirth, in the conviction that we can overcome or control nature with the help of technology. From that point of view, the $20^{\text {th }}$ century was marked by drastic changes in childbirth practices and even the concept of pregnancy and childbirth in general, changes that were for the most part accepted by women. Physiological processes, pregnancy and childbirth became medicalized. The body of the woman and the foetus within were under the control of medicine (Fox and Worts, 1999).

In Slovenia, as in many other European countries, especially those under the control or influence of the former Soviet Union, childbirth became entirely medicalized. Even after the political regime changed, there were no moves made to make childbirth more humane (Wagner, 2007), even though steps have been taken to make perinatal care more woman-oriented in the last decade. Trends towards more humane childbirth, which is to say closer to natural childbirth, are the result of the advocacy of doctors, 
midwives and women who wish to change the way women give birth in today's society. Despite that, the truth about what is good and what is not lies somewhere between medicalized and "natural". Therefore, the purpose of this paper is to present the main characteristics of both concepts, medicalization of pregnancy and childbirth, and natural childbirth, and highlight the most substantive critiques of both approaches. In addition to a general overview of the theme, the review focuses on the Slovenian context.

\section{Definition of medicalization}

Sociologists are interested in researching the medicalization phenomena but there is no definitive meaning of the concept. What is not in dispute regarding the definition of medicalization is that it means the expansion of medical jurisdiction and its use as a mechanism of social control through the medical gaze and surveillance (Brubaker and Dillaway, 2009). Christiaens and van Teijlingen (2009: 123) distinguish three meanings within the first generation of medicalization theories. Namely, the origin of the medical model, which refers to the origin of medical knowledge; medical imperialism, suggesting a growing number of life domains and social problems defined in terms of health and illness; iatrogenesis, in which medicalization is interpreted as an exaggeration of medical control. The second generation medicalization theory added a new meaning to the concept: the optimization of normal characteristics or processes. Hence, normal phenomena become problematic and a new consumer market is created (Christiaens and van Teijlingen, 2009: 123).

The term "medicalization" was first used in the 1970s, when the American sociologist Irving K. Zola (1972) pointed out the influence of medicine as an institution of social control and thus its increased influence on the everyday life of individuals. ${ }^{1}$ Zola went so far as to suggest that medicalization is capable of affecting, even excluding, more traditional institutions such as religion and law, claiming that it was becoming the new repository of truth, the place where absolute and often final judgments are made by supposedly morally neutral and objective experts. And these judgments are made not in the name of virtue or legitimacy but in the name of health.

\footnotetext{
${ }^{1}$ The increased influence of medicine became a matter of discussion after 1950 when various authors explored the importance of the concept of psychiatric and mental disorders and psychotherapy in relation to criminal acts, delinquency and behavioural problems (Davis, 2006).
} 
To Zola, this was happening in such a way that medicalization had begun intruding into the everyday life of individuals; medicine and labels such as "health" and "disease" were acquiring broader social meaning (Zola, 1972: 487). That is where Zola saw the biggest problem of medicalization: he and his acolytes thought that medicine exceeded its acceptable jurisdiction. ${ }^{2}$ Accordingly to Abbott (1988), professions do not operate individually but rather as a system. As he explains it, various professions are always in competition with one another. Their goal is to secure their own position in the marketplace, to control valuable jurisdictions and enlarge them. The latter is clearly associated with legitimate social power and control (Freidson, 1988). Davis (2006) points out that medicalization was initially based on a specific social process, the expansion of the jurisdiction of medicine as a profession, whereas the use of the term medicalization today implies the use of medical terminology for every definition or description of a problem or treatment via medical intervention.

After four decades, the concept of medicalization still remains highly disputable. According to White (2002), medicalization has increasing consequences because more and more areas are exposed to expanded medical control; the border between the desired and undesired or, rather, normal and pathological, is supposed to be drawn by experts based on socially and culturally neutral biological/physiological criteria. That seemingly objectifies measurements and criteria for classification and, at the same time, minimizes the connection between definition and social factors. Peter Conrad (1992: 210-211), one of the most important authors describing medicalization, asserts that it is a process by which non-medical problems become defined and treated as medical problems, usually in terms of illnesses or disorders. Medicalization consists of defining a problem in medical terms, using medical language to describe a problem, adopting a medical framework to understand a problem, or using a medical intervention to treat it. It is also a sociocultural process that may or may not involve the medical profession, leading to medical social control or medical treatment, or be the result of an intentional expansion by the medical profession. In his opinion, medicalization can happen on various levels: (1) conceptual, using medical terminology, with which we

\footnotetext{
${ }^{2}$ Eliot Freidson (1988: 249) wrote: "What has been called crime, lunacy, degeneracy, sin, and even poverty in the past is now being called illness, and social policy has been moving toward adopting a perspective appropriate to the imputation of illness."
} 
describe a problem, (2) institutional, using a legitimate medical approach to explore a problem or (3) an interactional level with doctor-patient interaction, whereby the doctor specifies the problem as medical and begins treatment. Davis (2006) objects to Conrad's definition of medicalization partly because he claims that today's use of medical terminology and the medical model are not limited only to the medical profession. ${ }^{3}$ Any group or individual's use of such terms/frameworks represents an instance of medicalization. Conrad and Barker (2010: 74) claim that medicalization has expanded beyond medical professionals, social movements and organizations to biotechnology, consumers and the insurance industry. There is evidence that the pharmaceutical industry plays a pivotal role in the shaping and disseminating of medical knowledge to promote their products (Williams and Calnan, 1996; Conrad and Leiter, 2004; Bezenšek and Barle, 2007; Conrad and Barker, 2010).

Like Conrad (1992, 2007) and Zola (1972), Reissman (1983: 4) claims that medical practice becomes a vehicle for eliminating or controlling problematic experiences that are defined as deviant, for the purpose of securing adherence to social norms. In this context, Conrad (1992: 216), based on the work of Foucault, distinguishes among four types of medical social control: (1) medical ideology, (2) collaboration, (3) technology and (4) medical surveillance. Medical ideology imposes a medical model primarily because of accrued social and ideological benefits; medical cooperation presents doctors in the role of informants, gatekeepers, institutional agents and technicians; medical technology suggests the use of medical technological means for social control, especially drugs, surgery and genetic or other types of screening; medical surveillance as a form of medical social control suggests that certain conditions or behaviours become perceived via a "medical gaze" and that physicians may legitimately lay claim to all activities concerning the condition. Helman (2007) suggests that the process of medicalization has undoubtedly been successfully assisted by advances

\footnotetext{
${ }^{3}$ The medical model or (more often used) biomedical term is the prevailing model in modern medicine. The biomedical framework tries to explain occurrences through the gradual separation of the non-essential from the essential. It is based on a conviction of a human dualism between body and soul, on biological reductionism and a linear connection between cause and effect. The model supposes that there is a biophysical explanation for every disease, which can be objectively defined. The observer of occurrences, or analyst, must be as objective as possible and removed from the activity being observed. The observer's primary characteristic is to focus on a disease (Švab, 1999).
} 
in medical technology, which serve further to reinforce peoples' dependence on the medical profession for the solutions of their problems.

\section{Medicalization of pregnancy and childbirth}

Pregnancy is a physiological state and is not an illness, even though Western civilization generally describes it as a risky condition (Riessman, 1983; Behruzi et al., 2010). ${ }^{4}$ The latter is important for understanding medicalization because, in this context, the perception of illness is seen as a problem or deviation that is appropriately rendered to the field of medicine, as is the case with childbirth and pregnancy. Control over the process of childbirth has become an important task of medicine. Interventions have been developed with the objective of making birth safer and less painful. New technologies have also focused on monitoring mother and foetus during pregnancy (Smeenk and ten Have, 2003: 153) and childbirth, with the final goal that a healthy child will be born to a healthy mother. Along with this, questions have subsequently arisen regarding means of achieving this goal and a pregnant woman's control over her own body. Pahor (1999) states that a dominant conviction has evolved that pregnancy and childbirth should be supervised both medically and legally, that it has become unacceptable for people to decide about these - now medical matters - themselves, that de-medicalization of pregnancy and childbirth would in some way be a threat to the social order. The pregnant woman's body has become construed as uncontrollable, uncontained, unbounded, unruly, leaky ${ }^{5}$ and wayward (Carter, 2010). Such a construct can be found in popular culture, social theory and even among women. Many debates and critiques involving this issue, particularly the aspect of control over the body, have of course been engendered and the assumptions that allowed the medicalization of pregnancy and childbirth are now being challenged (Oakley, 1979; Davis-Floyd, 2001).

Before the $20^{\text {th }}$ century, pregnancy and childbirth were accepted as natural processes and treated as such. Childbirth was a social and emotional event that usually took place in the pregnant woman's home and the whole

\footnotetext{
${ }^{4}$ In 1949, the Slovene teacher of midwifery, gynaecologist and obstetrician, Dr. Vito Lavrič (1949: 98) wrote: "Pregnancy is not a disease; it is a natural condition that is tightly bonded with the structure and activity of the female body."

${ }^{5}$ The meaning of the term "leaky" is related to vomiting (morning sickness), crying (emotional state), frequent urinating, breastfeeding (milk production), sweating, blood loss during delivery, amniotic fluid etc.
} 
family was a part of the process in one way or another. The mortality of mothers and infants during childbirth, though, was high (Riessman, 1983; Zwelling, 2008). With the development of obstetrics at the beginning of the $20^{\text {th }}$ century and a tendency towards a decreasing mortality rate, childbirth began moving into the hospital. In Slovenia, the process began intensively after 1950 (Borisov, 1995). Childbirth slowly became a medical event, midwives were pushed out of the birthing process by medicine, women during childbirth were included in a medical model of care, and breastfeeding was replaced by the development of milk formulas (Prosen and Prosen, 2011). Because of risks and complications that might occur during pregnancy and childbirth, the process became a focus of attention for the medical community and gradually fell under medical surveillance (Riessman, 1983). Walsh (2007: 226) delineates three imperatives of surveillance for a woman entering a maternity hospital: (1) a clinical imperative, whereby an appropriate and satisfying process of childbirth is ensured, (2) an organizational imperative, which means that her movement is limited to the maternity room and where her seamless care is assured and (3) a professional imperative, which is connected with submitting to the rules/instructions of medical personnel. Young (1998: 280) argues that the medicalization of pregnancy and childbirth leads to isolation or alienation and explains that it means objectification or appropriation by one subject of another subject's body, actions or the outcomes of those actions. He believes that the medical profession develops and controls knowledge in three ways: (1) by in effect defining pregnancy as a medical disorder, (2) by using medical instruments for the understanding of internal processes and (3) through employing a medical setting, which justifies control over the woman's body and her pregnancy. It can be understood in the light of the last named that, within medicalization, the needs and desires of the pregnant woman are rarely heard. These circumstances isolate the pregnant woman from her lived experiences, ignored through the construct of knowledge that surrounds pregnancy and childbirth in this environment (Parry, 2008). Young (1998: 274) claims that women have thus become a mere container for developing a foetus, which positions pregnancy as an object and sets up an imperative for pregnant women to take care of their bodies.

The social conceptualization of pregnancy and childbirth as an illness led to the development of technology and to an increase in the number of medical interventions in the field of obstetrics practice. Conceptualization 
of pregnancy and childbirth as a risky condition can be viewed as a cause of technology development, but also as an effect. According to Maturo (2012: 124), new diagnostic tools also mean more chances of discovering illnesses. Davis-Floyd argues that with the use of technology to control a hazardous process, the aim is to impress women with the conviction that technology is superior to nature. This, together with medical interventions, provides women with a sense of control over a potentially dangerous process. Among these interventions, the following are most common: cardiotocography, epidural analgesia, amniotomy, induction of labour, elective caesarean section and episiotomy (Behruzi et al., 2010). ${ }^{6}$ Davis-Floyd (1994) suggests that such kinds of interventions further place the mother in the role of patient and reduce her sense of control over her own body. Riessman (1983) and Cahill (2001) agree that medicalization of childbirth is leading to such changes as an increasing number of caesarean sections in the USA and Great Britain.

In 2009 in Slovenia, there were 3700 caesarean sections, which represented $17.3 \%$ of all deliveries; $41.2 \%$ of all caesarean sections were elective or planned. The percentage of newborns delivered via caesarean section is rapidly increasing in Slovenia. Between 1999 and 2009, it increased by $76.6 \%$ (from 101.2 to 178.7 per 1000 newborns), which is still below the EU average. At this point, there are significant differences among maternity hospitals. The percentage of caesarean sections in 2009 varied between $10.6 \%$ and $22.0 \%$. Vacuum deliveries represented $3.1 \%$ of deliveries, that percentage varying between $1.3 \%$ and $8.7 \%$ among maternity hospitals. ${ }^{7}$ Episiotomy was done during $31.6 \%$ of deliveries, ranging from $24.5 \%$ to $48.7 \%$ in different maternity hospitals. Statistical data for Slovenia other-

\footnotetext{
${ }^{6}$ Cardiotocography is a diagnostic method by which the foetal heartbeat and uterus contractions are constantly measured during pregnancy or delivery. Epidural analgesia is a technique of regional anaesthesia that can be used on a specific part of a body with the patient remaining conscious. Amniotomy is an artificial rupturing of the amniotic sac or stripping of the amniotic membrane. Induction of labour can be defined as inducing contractions with the help of medication (oxitocyn derivatives). Caesarean section or abdominal section is childbirth of the foetus through incision through the abdominal wall and incision through the wall of the uterus (Pajntar, 2004). Elective means planned caesarean section. Episiotomy means cutting of a segment of the perineum to enlarge the passage for the foetus during childbirth.

${ }^{7}$ Vacuum extraction of the foetus means delivery of the foetus with the help of a vacuum. The obstetrician places a rubber or metal suction cup on the foetus' head and with vacuum pressure slowly pulls the foetus through the birth canal.
} 
wise shows a decrease in the length of stay in maternity hospitals after childbirth. The average hospitalization for mothers after childbirth was 4.0 days in 2009, less than in 2008. Meanwhile, the percentage of pregnant women that were not hospitalized during pregnancy was $82.6 \%$ in 2009 , while the percentage of pregnant women that were hospitalized once was 13.8\% (Inštitut za varovanje zdravja Republike Slovenije, 2011: 9).

The Slovene obstetrician Pajntar (2004: 323-324) agrees that an increase in caesarean sections coincides with the development of techniques such as ultrasound and cardiotocography; with women with serious illnesses delivering babies; with improved safety of women in surgical delivery; with the increased tendency of surgically oriented obstetricians who transfer the experiences of others into their institutions without critical review; and with obstetricians with less experience working in maternity hospitals with a lower number of deliveries, who are no longer able to perform various surgical procedures. Reissman (1983) points out that it is important from the view of understanding the medicalization process that the decision to perform a caesarean section is placed entirely in the doctor's hands, while vaginal deliveries are organized differently and are mostly supervised by midwives. In Pajntar's (2004) opinion, there are more caesarean sections in the USA because deliveries are mostly handled by doctors. The perinatal statistical data of Slovenia mentioned previously raises the legitimate question of whether the same applies to Slovenia. Deliveries are handled by midwives but the number of caesarean sections is significantly increasing. Lee, Khang and Lee (2004: 108-109) argue that even though physicians are presumed to be most responsible for high caesarean rates and inter-hospital differences in those rates, women might also contribute to the decision for a caesarean delivery. Elective caesarean is becoming a chosen mode of delivery. Graham et al. (1999) established that a preference for elective caesarean section is not rare among women. This results in many disagreements among proponents of alternative birth and high-tech obstetrics (Beckett, 2005; Bergeron, 2007).

\subsection{Natural or normal childbirth}

To discuss medicalization is to discuss the dichotomy between the "natural" and the medical. Through the process of medicalization, natural physiological processes like pregnancy and childbirth have become pathological events, justifying medical jurisdiction and control. "Natural" has developed 
a negative connotation within the medical model, even though cultural evaluations of the natural have become more acceptable in recent years, especially in relation to the increasing use of natural products (Brubaker and Dillaway, 2009). However Brubaker and Dillaway emphasize that there is a lot of selectivity involved in the cultural valuation of "natural" as positive. For example, a patient refusing medical treatment or a woman deciding to deliver a baby at home, is usually construed negatively or as being socially unacceptable. Maturo (2012: 122-123) explains that manipulation and transformation of human nature by biomedical technology is increasing. We are living in a society that is becoming increasingly bionic. Biology and genetics are seen as the main forces that affect human life, with social factors playing a minor role.

Humanizing birth means understanding that the woman giving birth is a human being and making certain that the woman's experience while giving birth is fulfilling and empowering. This makes a woman strong and therefore makes society strong (Wagner, 2001: S25). In Wagner's (2001) opinion, humanization of childbirth empowers women and their care providers by taking into consideration humanized values such as women's emotional state, their values, beliefs and senses of dignity and autonomy during childbirth. The woman becomes the centre of childbirth and control, whereby she makes all the decisions about what will happen; neither a doctor nor anybody else is authorized to take over any longer. The tendency toward humanization is not limited to pregnant women only; medical workers, especially midwives, and some medical non-governmental and governmental organizations and associations are also promoting natural childbirth. A majority of supporters of the humanization of childbirth advocate a natural model of childbirth in which women have more agency in the process. Women would pay attention to their bodies' signals and follow their bodies' cues rather than responding to the cues of medical technology. In this model, women would use their own psychological resources and natural techniques to control pain (Martin, 2003). Nevertheless, Zadoroznyj (1999) believes that even this natural childbirth model requires some control over a woman's body, whether or not this control is medicalized. Oakley (1979) describes natural childbirth as an opposition to hospitalization, to technology and to the use of pharmaceutical means to ease pain. It entails consciousness and control, the active role of the mother as a person in the process of childbirth, and the primacy of her needs, rather than the depend- 
ent and inactive role of the mother as a medical patient. She explains that the term "natural" itself is confusing and unclear, that there are two clear meanings of the word. The first meaning refers to the notion that technology is excluded from the childbirth process and the second, that childbirth is animalistic, so that basic animal instincts are included in the childbirth process.

Darra (2009) also discusses the controversy of designating the natural. She highlights the difference in designation between natural and normal childbirth. While natural childbirth was the force behind a movement with the same name in the 1970s and 1980s, as a reflection of resistance to medicalization, the expression "normal childbirth" is now more commonly used. According to Darra, definitions describing normal childbirth emphasize that normal childbirth means childbirth without the use of invasive medical interventions, without induction of labour and without using local or general anaesthesia. Wagner (1994) describes different concepts of what normal childbirth actually represents to different professional groups, showing dissonance in the recognition and understanding of normal childbirth (Table 1).

The Lamaze International (2007) determines that a normal childbirth is one that takes place with the recognition that a woman's body is capable of growing a healthy baby during pregnancy, giving birth without routine interventions that can disrupt normal body processes and nurturing the baby after birth by breastfeeding. Accordingly, Zwelling (2008) identified six criteria or recommendations for normal childbirth: (1) childbirth begins spontaneously, (2) freedom of movement throughout childbirth, (3) continuous support during childbirth, (4) childbirth without using routine interventions, (5) using non-supine positions during childbirth and (6) no separation of the mother and the newborn after birth, suggesting unlimited opportunity for breastfeeding. In comparison, the National Childbirth Trust (2007), established in 1965 in Great Britain, places among the main goals of natural childbirth (1) humane care of women during pregnancy and childbirth, during which the woman should not be forced into anything or be derided in any way, (2) analgesia should not be forced on the woman in childbirth (and) nor should labour be induced merely to save time and (3) the idea that childbirth routinely includes internal gynaecological examination, usage of analgesia and episiotomy must be eradicated.

Defining normal childbirth, especially criteria on the basis of which we can define natural childbirth, is complicated because the difference in 
the definition can substantially increase or decrease the number of women whom we can say have had a natural childbirth, and that can be misleading. On the other hand, natural childbirth includes an ideology that could also be misused to condemn women that do not go through childbirth without any medical intervention, even though they would like to have a natural childbirth. The Danish philosopher Wackerhausen (1999: 106) criticizes those who would dismiss certain interventions with the aim of achieving what they see as the "natural". As he says, using such expressions as "natural" or "normal" in discussions about technology and medicine, health care and childbirth are more of a burden than a blessing, more a source of confusion than a source of clarification. In the name of nature, unbearable suffering and misery might potentially be tolerated and encouraged, and some highly technological interventions and treatments could also be discouraged under that name. Wackerhausen believes that what is good is what is essential and worth following.

In addition to the already mentioned critique of notions of the "natural", Brubaker and Dillaway (2009) discuss the notion that the natural childbirth approach denies women choice and agency, "essentializes" women's childbirth experiences, reflects class and race bias and expands the medical gaze. As they explain, the natural childbirth approach places greater pressure on women to be "natural" mothers, as if it were merely biologically inherent. That kind of explanation distinguishes between "natural" and "artificial" childbirth, with which it recreates the historical view of women as simple and instinctual creatures that are in close connection with nature, while men are rational and scientific. Class and racial biases are founded on the rationalistic economic ideology of a middle class that emphasizes control over childbirth and informed consumer choice and requires access to cultural and material resources accessible only to privileged women. Middle class women, compared to working class women, are more dedicated in their appreciation of the possibility of control over every part of life, including control over the childbirth process (Martin, 1990; Lee, Khang and Lee, 2004). Connected with racial biases, Brubaker and Dillaway (2009) pointed out the case of racial stereotypes of British midwives concerning Asian women. It can be concluded that the meaning and decision in favour of natural childbirth depends on many social, cultural and socio-economic factors and these are not necessarily related to the idea of the "natural". 
Table 1. Definitions of normal childbirth by different professionals

\begin{tabular}{|c|c|}
\hline Professional group & Definition \\
\hline Obstetrician & $\begin{array}{l}\text { Normal childbirth is one that does not have pathological } \\
\text { abnormalities and has no medical interventions. }\end{array}$ \\
\hline Epidemiologist & $\begin{array}{l}\text { Normal childbirth is completely natural, but the process of } \\
\text { medicalization has made it awkward to measure it. }\end{array}$ \\
\hline Psychologist & $\begin{array}{l}\text { Childbirth is related to the woman's life cycle and her } \\
\text { transition through motherhood supports her progression } \\
\text { towards full womanhood. }\end{array}$ \\
\hline Anthropologist & $\begin{array}{l}\text { Western society is progressively changing childbirth into a } \\
\text { pathological activity. }\end{array}$ \\
\hline Sociologist & $\begin{array}{l}\text { Childbirth is not a normal process but rather a social } \\
\text { process, in which the outcome is affected by the woman } \\
\text { herself and her environment. }\end{array}$ \\
\hline Midwife & $\begin{array}{l}\text { Normal childbirth is childbirth that the woman saw as } \\
\text { normal, in which she was involved and it fits her frame of } \\
\text { reference because childbirth is part of the life process. }\end{array}$ \\
\hline
\end{tabular}

Source: Wagner, 1994: 420.

\subsection{The feminist view of the medicalization of pregnancy and childbirth}

Why does medicalization affect women more than men? Although men and women do seem to have unique biological advantages and disadvantages in relation to each other, substantial variation occurs and these seem to vary with certain conditions. A growing number of researchers have recognized that social and biological factors interact in a complex way. Women's social position mediates access to the positive and negative social and environmental factors that occur at the individual, household, community and social level (Bird and Rieker, 2008). Riessman (1983: 58) elaborates why women's problems have been disproportionately medicalized: (1) the matching of women's biology and medicine's biomedical orientation. Women have external markers (menstruation, childbirth, lactation and the like), whereas natural processes are more hidden in men, and as such are subjected to greater influence of medicine. In addition, contributions to increased medicalization for women are (2) their social roles and (3) their greater exposure to medical labelling because of their patterns of dealing with their own symptoms, in conjunction with the medical response to this phenomenon. Riessman explained that, because of their maternal 
role, women interact more with the medical community. Women visit doctors more often than men do, and their visits are usually longer, including more examinations, questions and check-ups in regard to their reproductive health. Finally, it is worth mentioning (4) the relatively submissive position of women in society, which led to the point at which women were a group especially vulnerable to the expansion of medicine. Conrad (2007), however, points out that while the medicalization of women's bodies and difficulties continues, men are now being increasingly medicalized, especially aging males.

The Slovenian researcher Zalka Drglin (2007: 106-107) established that involvement in various discourses and practices is a feature of modern motherhood and, among them, the medical discourse is especially determinative. Specific images of motherhood are more desirable than others and they are used as a strong regulatory ideal, influencing the life of all women, not just mothers. At the point of conception, a woman is confronted with more or less direct messages that she receives through health care and in which normative ideas and expectations about suitable motherhood are expressed. In Drglin's opinion, medicalization is a clear fact when we consider that the majority of modern pregnant women do not even ask where the childbirth will take place because it is assumed that she will go to a maternity hospital. Furthermore, the paradox arises of pregnant women complaining about reduced numbers of ultrasound check-ups because these represent gestures of good care for them and the baby, even though there are serious doubts about the need for and ultimate effect of using ultrasound too many times. The gap between the critique of the medicalization of pregnancy and childbirth and the experiences of women could be reduced by focusing attention on the societal context of childbirth and the circumstances in which the childbirth is happening. It is obvious that material and social conditions influence motherhood and shape the perspective of women and their experiences of childbirth (Fox and Worts, 1999).

After 1960, feminist concepts expressed through organized feminist movements offered powerful resistance to the social roles of women connected with childbearing and raising children (Brubaker, 2007). Oakley noted that in that period, the views of feminism on natural childbirth were ambivalent. Some feminists saw the role of technology in reproduction as a reason for the absolute alienation of women and evidence of the predetermination of technology involved in childbearing (Oakley, 1979). Feminism 
did not conceptualize reproduction as a female source of power but rather as a handicap, a source or cause of social inferiority. After 1980, a second

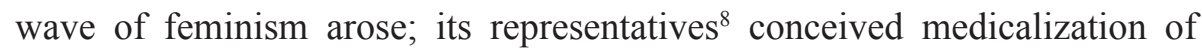
childbirth as the control of medicine over a woman's body, her choices and decisions regarding her reproductive abilities. The second wave feminism positions women in the light of "normality" and "naturality". In this perspective, women are viewed as the natural, normal experts in childbirth, and their control over the childbirth process and their choices for how it progresses are deemed preferable to the authority and control of medicine (Brubaker and Dillaway, 2009: 35).

Fox and Worts (1999) elaborated a critique of medicalized childbirth and emphasized that the medicalization of pregnancy and childbirth not only decreases the control of a woman over her body but also fails to improve the physical and emotional outcome of the birth, and even alienates the woman from a potentially empowering experience. Drglin (2007) discusses Barbara Katz Rotham's claim that childbirth is not just about giving birth to a child but also giving birth to a mother - powerful, competent, capable mothers that trust themselves and realize their inner power. In that respect, each woman is unique, states Drglin (2007), which is why we discuss many different attitudes and beliefs about childbirth. Women travel through pregnancy based on their own ethical beliefs, various levels of integrity, respect and control. They position childbirth into their lives in regard to their own beliefs and life practices. The latter are changeable, in respect to their changeable relationships and experiences through time.

The possibility of women taking control over their bodies during pregnancy and childbirth brings about two important elements of autonomy: the possibility of choosing a place to give birth and the use of medical technology or medical interventions during pregnancy and childbirth. Davis-Floyd (1992) argues that childbirth is a ritual of transition into motherhood. In her opinion, the purpose of the various hospital rites organizing medicalized childbirth is to socialize women in accord with the culture's main beliefs. With the use of technology to control what is seen as a potentially dangerous process, the aim is to impress women with the conviction that technology (and related intervention) is superior to nature, with its possibility of controlling the outcome and, consequently, providing a sense of control for women.

${ }^{8}$ The main representatives were Ann Oakley, Robbie Davis-Floyd, Catherine Kohler Riessman, Emily Martin, among others. 


\section{Discussion}

Statistical data, especially the increased number of caesarean sections in Slovenia (Inštitut za varovanje zdravja Republike Slovenije, 2011), other European countries (Cahill, 2001; Behruzi et al., 2010) and the USA (Conrad, Mackie and Mehrotra, 2010), yet again confirms the biomedical attitude to pregnancy and childbirth. Nevertheless, in Slovene society we can detect a tendency towards a less medicalized model of perinatal care that has been promoted by midwives, some obstetricians and women who want different treatment, in many cases to obtain the possibility of making their own decisions, or at least of becoming more involved in their childbirth process. From this perspective, it is even possible to talk about an organized social movement. ${ }^{9}$ Drglin (2007: 110) argues that, in the Slovenian system of maternity care, professionals often define a woman by the position of their own unreflected medical knowledge and according to the degree of her conformity. Women who co-operate within this system are understood as "less problematic", while women, usually called "alternative", who ask a lot of questions, have different expectations, are marked as problematic. The first efforts have been made, including the opening of a birth centre "Midwives House" 10 in 2011, in which midwives work autonomously, representing a degree of compromise between childbirth in a maternity hospital and a "natural childbirth". This "experiment" strongly relates to Davis-Floyd's (2001: S5) humanistic and holistic paradigm of childbirth. The prevailing technocratic model stresses mind-body separation and sees the body as a machine. In contrast, the humanistic model emphasizes the mind-body connection and defines the body as an organism, while the holistic model insists on the oneness of body, mind and spirit and defines the body as an energy field in constant interaction with other energy fields. According to Walsh (2007: 216), the birth centre actualizes a number of contrasting ways of "being" and "doing" that appear to serve well the interests of both staff and women. In particular, the "nomadic" midwifery practice and a "care as gift" orientation challenges the biomedical model that defines the parameters of normal and the "vigil of care" discourse that regulates the professional/patient relationship.

Feminists and supporters of natural childbirth detail and promote the advantages of natural childbirth, but mostly of privileged women (Brubaker

\footnotetext{
${ }^{9}$ http://www.mamazofa.org

${ }^{10} \mathrm{http}: / /$ www.bolnisnica-po.si
} 
and Dillaway, 2009) who can afford that possibility, whether in Slovenia or in one of the neighbouring countries; for example in Austria, where the network of natural childbirth providers is more widespread. For a majority of women, natural childbirth is still considered a heresy because of the established opinion that it puts both mother and child at risk. A decrease in the use of medical interventions can also be perceived as an element of a reduced quality of health care (Drglin, 2007). The process of medicalization of pregnancy and childbirth contributed largely to such beliefs, perhaps inseparably from popular culture, which forms such societal values in the informational and technological era. Technology usually overcomes the desire for the natural, especially when the health of an unborn child is perceived to be at stake. Finally, it must be acknowledged that some invasive and non-invasive technological innovations significantly reduced the mortality of mothers and babies over the course of the $20^{\text {th }}$ century. In particular, incubators, artificial insemination and the sheer development in medical care has undeniably contributed to better outcomes of pregnancy and childbirth, and even made it possible for some women to live the experience who could not otherwise have done so.

A consequence of the obvious medical advances has been less concern over women's control over their own bodies. Discussions about pregnancy and childbirth evolve into a false dichotomy, the choice between the desire for healthy offspring as "opposed" to woman's self-governance of her own body. What can be criticized in the medicalization process is especially the lack or denied control of women over their own bodies. The prevailing biomedical model does not include a holistic approach that follows the will of the woman either in childbirth or during the course of childbirth. Informed choice is also questionable. Established doctrine often dictates unnecessary routine procedures, such as enemas and shaving. There is no scientific evidence that either is necessary or contributes to or in any way alters the course of childbirth. The pointlessness of these procedures cannot be doubted if it is insisted that medical practices must be based on scientific data, verified within the framework of medical science (Drglin, 2007). At the very least, such cases reflect the persistent dominance of the Cartesian concept of dualism regarding the human body, which must be scientifically (even if only virtually) rationalized, controlled and disciplined through or with technology (Bezenšek and Barle, 2007). A similar case of childbirth practice, described by Drglin (2007), is the consumption of food 
and drinks during childbirth. In Slovenia, we are gradually departing from the total banishment of food and drinks.

Discussions about the medicalization of pregnancy and childbirth and natural childbirth lead to some perhaps inevitable ambivalence, since technological advances save lives as well as dehumanize. The definition of "natural" is not entirely clear and, in connection with medicalization, often obscures the fact that pregnancy and childbirth are social constructs and that the perception of both influences the creation of an idealized image of pregnancy and childbirth. Any deviation from an existing prevalent construct is therefore treated as excessive and condemned by society. The complexity involved in pregnancy and childbirth in the light of medicalization versus a natural approach demands comprehensive analysis. Brubaker and Dillaway (2009) warn that current studies about the dichotomy between natural and medicalized are rare compared to those in the 1970s and 1980s, which may suggest that interest in the controversy is waning. Both have seemingly become a completely normal part of life, even though that is not really the case. The lived experience of pregnancy and childbirth accompanies a woman throughout her life. Taking into account the fact that maternity represents a great change in a woman's life, understanding the meaning of the process of pregnancy and childbirth as a beginning of a transition of roles, is extremely important (Davis-Floyd, 1992). This is reason enough to study pregnancy and childbirth not only from the scientific perspective but also as a very sensitive human issue specific to women, which can contribute to overcoming stereotypical cognition of these two virtually incompatible approaches to the process.

\section{REFERENCES}

Abbott, Andrew (1988). The System of Professions: An Essay on the Division of Expert Labor. Chicago: University of Chicago Press.

Barker, Kristin K. (1998). "A ship upon a stormy sea: The medicalization of pregnancy”, Social Science \& Medicine, 47 (8): 1067-1076. doi: 10.1016/S02779536(98)00155-5

Beckett, Katherine (2005). "Choosing Cesarean: Feminism and the politics of childbirth in the United States", Feminist Theory, 6 (3): 251-275. doi: $10.1177 / 1464700105057363$

Behruzi, Roxana, Hatem, Marie, Fraser, William, Goulet, Lise, Ii, Masako and Misago, Chizuru (2010). "Facilitators and barriers in the humanization of childbirth practice in Japan", BMC Pregnancy and Childbirth, 10 (25): 1-18. doi: $10.1186 / 1471-2393-10-25$ 
Bergeron, Véronique (2007). "The Ethics of Cesarean Section on Maternal Request: A Feminist Critique of the American College of Obstetricians and Gynecologists' Position on Patient-Choice Surgery", Bioethics, 21 (9): 478-487. doi: 10.1111/j.1467-8519.2007.00593.x

Bezenšek, Jana and Barle, Andreja (2007). Poglavja iz sociologije medicine. Maribor: Univerza v Mariboru, Medicinska fakulteta.

Bird, Chloe E. and Rieker, Patricia P. (2008). Gender and Health: The Effects of Constrained Choices and Social Policies. New York: Cambridge University Press.

Borisov, Peter (1995). Ginekologija na Slovenskem od nastanka do 80. let 20. stoletja. Ljubljana: Slovenska akademija znanosti in umetnosti.

Brubaker, Sarah Jane (2007). "Denied, Embracing, and Resisting Medicalization: African American Teen Mothers' Perceptions of Formal Pregnancy and Childbirth Care", Gender \& Society, 21 (4): 528-552. doi: 10.1177/0891243207304972

Brubaker, Sarah Jane and Dillaway, Heather E. (2009). "Medicalization, Natural Childbirth and Birthing Experiences", Sociology Compass, 3 (1): 31-48. doi: 10.1111/j.1751-9020.2008.00183.x

Cahill, Heather A. (2001). "Male appropriation and medicalization of childbirth: An historical analysis", Journal of Advanced Nursing, 33 (3): 334-342. doi: 10.1046/j.1365-2648.2001.01669.x

Carter, Shannon K. (2010). "Beyond control: Body and self in women's childbearing narratives”, Sociology of Health \& Illness, 32 (7): 993-1009. doi: 10.1111/j.1467-9566.2010.01261.x

Christiaens, Wendy and van Teijlingen, Edwin (2009). "Four meanings of medicalization: Childbirth as a case study", Salute e società, 8 (2): 123-142. doi: 10.3280/SES2009-EN2009

Conrad, Peter (1992). "Medicalization and Social Control", Annual Review of Sociology, 18 (1): 209-232. doi: 10.1146/annurev.so.18.080192.001233

Conrad, Peter (2007). The Medicalization of Society: On the Transformation of Human Conditions into Treatable Disorders. Baltimore: Johns Hopkins University Press.

Conrad, Peter and Barker, Kristin K. (2010). "The Social Construction of Illness: Key Insights and Policy Implications", Journal of Health and Social Behavior, 51 (1 Suppl.): S67-S79. doi: 10.1177/0022146510383495

Conrad, Peter and Leiter, Valerie (2004). "Medicalization, Markets and Consumers", Journal of Health and Social Behavior, 45 (1 Suppl.): S158-S176. doi: $10.2307 / 3653830$

Conrad, Peter, Mackie, Thomas and Mehrotra, Ateev (2010). "Estimating the costs of medicalization", Social Science \& Medicine, 70 (12): 1943-1947. doi: 10.1016/j.socscimed.2010.02.019

Darra, Susanne (2009). “'Normal', 'natural', 'good' or 'good-enough' birth: Examining the concepts", Nursing Inquiry, 16 (4): 297-305. doi: 10.1111/j.14401800.2009.00467.x

Davis, Joseph E. (2006). "How Medicalization Lost Its Way", Society, 43 (6): 51-56. doi: 10.1007/bf02698486 
Davis-Floyd, Robbie (1992). Birth as an American Rite of Passage. Berkeley: University of California Press.

Davis-Floyd, Robbie (1994). "Culture and birth: The technocratic imperative", The Birth Gazette, 11 (1): 24-25.

Davis-Floyd, Robbie (2001). "The technocratic, humanistic, and holistic paradigms of childbirth", International Journal of Gynecology \& Obstetrics, 75 (Suppl. 1): S5-S23. doi: 10.1016/S0020-7292(01)00510-0

Drglin, Zalka (2007). "Vse najboljše za rojstni dan! Ranljivost in moč žensk v sodobnih porodnih praksah", in: Zalka Drglin (ed.). Rojstna mašinerija: sodobne oporodne vednosti in prakse na slovenskem. Koper: Založba Annales, pp. $105-156$.

Fox, Bonnie and Worts, Diana (1999). "Revisiting the Critique of Medicalized Childbirth: A Contribution to the Sociology of Birth", Gender \& Society, 13 (3): 326-346. doi: 10.1177/089124399013003004

Freidson, Eliot (1988). Profession of medicine: A study of the sociology of applied knowledge. Chicago: University of Chicago Press.

Graham, W. J., Hundley, V., McCheyne, A. L., Hall, M. H., Gurney, E. and Milne, J. (1999). "An investigation of women's involvement in the decision to deliver by caesarean section", BJOG: An International Journal of Obstetrics and Gynaecology, 106 (3): 213-220. doi: 10.1111/j.1471-0528.1999.tb08233.x

Helman, Cecil G. (2007). Culture, Health and Illness. London: Hodder Arnold Publication.

Inštitut za varovanje zdravja Republike Slovenije (2011). Perinatalni informacijski sistem Republike Slovenije: primerjava podatkov med regijami za leto 2009. Ljubljana: Inštitut za varovanje zdravja Republike Slovenije.

Lamaze International [2007]. "Position Paper - Lamaze For the 21st Century", http://www.lamazeinternational.org/p/cm/ld/fid=211.

Lavrič, Vito (1949). Porodništvo. Ljubljana: Mariborska tiskarna.

Lee, Sang-Il, Khang, Young-Ho and Lee, Moo-Song (2004). “Women's Attitudes toward Mode of Delivery in South Korea - a Society with High Cesarean Section Rates”, Birth, 31 (2): 108-116. doi: 10.1111/j.0730-7659.2004.00288.x

Martin, Emily (1990). "The Ideology of Reproduction", in: Faye Ginsburg and Anna Tsing (eds). Uncertain Terms: Negotiating Gender in American Culture. Boston: Beacon Press, pp. 300-314.

Martin, Karin A. (2003). "Giving Birth Like a Girl”, Gender \& Society, 17 (1): 54-72. doi: 10.1177/0891243202238978

Maturo, Antonio (2012). "Medicalization: Current concept and future directions in a Bionic Society", 10 (1): 122-133. doi: 10.4103/0973-1229.91587

National Childbirth Trust (2007). Making normal birth a reality: Consensus statement from the Maternity Care Working Party. London: National Childbirth Trust.

Oakley, Ann (1979). "A Case of Maternity: Paradigms of Women as Maternity Cases”, Signs, 4 (4): 607-631. doi: 10.2307/3173362

Pahor, Majda (1999). Sociologija za zdravstvene delavce. Ljubljana: Univerza v Ljubljani, Visoka šola za zdravstvo. 
Pajntar, Marjan (2004). “Carski rez”, in: Marjan Pajntar and Živa Novak-Antolič (eds). Nosečnost in vodenje poroda. Ljubljana: Cankarjeva založba, pp. 323-335.

Parry, Diana C. (2008). "We Wanted a Birth Experience, not a Medical Experience': Exploring Canadian Women's Use of Midwifery", Health Care for Women International, 29 (8-9): 784-806. doi: 10.1080/07399330802269451

Prosen, Jana and Prosen, Mirko (2011). “1.-7. avgust 2011: teden dojenja”, Zdravje za vse, http://www.zzv-kp.si/wp-content/uploads/Casopis_ZdravjeZaVse_No8www.pdf.

Riessman, Catherine Kohler (1983). "Women and medicalization: A new perspective”, Social Policy, 14 (1): 3-18.

Smeenk, Anke D. J. and ten Have, Henk A. M. J. (2003). "Medicalization and obstetric care: An analysis of developments in Dutch midwifery", Medicine, Health Care and Philosophy, 6 (2): 153-165. doi: 10.1023/a:1024132531908

Švab, Igor (1999). "Bolnik s kronično boleznijo v ambulanti družinske medicine", in: Igor Švab (ed.). Vodenje kroničnega bolnika v družinski medicini: zbornik 16. učnih delavnic za zdravnike družinske medicine. Ljubljana: Združenje zdravnikov družinske/splošne medicine, pp. 9-14.

Wackerhausen, Steen (1999). "What is natural? Deciding what to do and not to do in medicine and health care", BJOG: An International Journal of Obstetrics and Gynaecology, 106 (11): 1109-1112. doi: 10.1111/j.1471-0528.1999.tb08132.x

Wagner, Marsden (1994). Pursuing the birth machine: The search for appropriate birth technology. Camperdown: ACE Graphics.

Wagner, Marsden (2001). "Fish can't see water: The need to humanize birth", International Journal of Gynecology \& Obstetrics, 75 (Suppl. 1): S25-S37. doi: 10.1016/S0020-7292(01)00519-7

Wagner, Marsden (2007). "Evolucija k žensko osrediščeni oporodni skrbi", in: Zalka Drglin (ed.). Rojstna mašinerija: sodobne oporodne vednosti in prakse na slovenskem. Koper: Založba Annales, pp. 17-30.

Walsh, Denis J. (2007). "A birth centre's encounters with discourses of childbirth: How resistance led to innovation", Sociology of Health \& Illness, 29 (2): 216-232. doi: 10.1111/j.1467-9566.2007.00545.x

White, Kevin (2002). An Introduction to the Sociology of Health and Illness. London: Sage.

Williams, Simon J. and Calnan, Michael (1996). "The 'limits' of medicalization? Modern medicine and the lay populace in 'late' modernity", Social Science \& Medicine, 42 (12): 1609-1620. doi: 10.1016/0277-9536(95)00313-4

Young, Iris (1998). "Pregnant embodiment", in: Donn Welton (ed.). Body and flesh: A philosophical reader. Malden: Blackwell Publishers Ltd, pp. 274-285.

Zadoroznyj, Maria (1999). "Social Class, Social Selves and Social Control in Childbirth", Sociology of Health \& Illness, 21 (3): 267-289. doi: 10.1111/14679566.00156

Zola, Irving Kenneth (1972). "Medicine as an institution of social control", The Sociological Review, 20 (4): 487-504. doi: 10.1111/j.1467-954X.1972.tb00220.x

Zwelling, Elaine (2008). "The Emergence of High-Tech Birthing", Journal of Obstetric, Gynecologic \& Neonatal Nursing, 37 (1): 85-93. doi: 10.1111/j.15526909.2007.00211.x 


\title{
Sociološka konceptualizacija medikalizacije trudnoće i poroda: implikacije u Sloveniji
}

\author{
Mirko PROSEN \\ Fakultet zdravstvenih znanosti, Sveučilište Primorska, Slovenija \\ mirko.prosen@fvz.upr.si \\ Marina TAVČAR KRAJNC \\ Odsjek za sociologiju, Filozofski fakultet, Sveučilište u Mariboru, Slovenija \\ marina.tavcar@um.si
}

U radu se propituje medikalizacija trudnoće i poroda, a ujedno i težnja za humanizacijom ili demedikalizacijom poroda. Tijekom prošloga stoljeća u zapadnim se zemljama koncept poroda dramatično promijenio. Trudnoću i porod još se na početku 20. stoljeća smatralo prirodnim pojavama. U drugoj polovini 20. stoljeća, istodobno $\mathrm{s}$ intenzivnim razvojem ginekologije i opstetricije, te njima srodnih tehnologija, trudnoća i porod našli su se u nadležnosti medicine. Medikalizacija, kako ju definira Peter Conrad, proces je kojim nemedicinski problemi postaju definirani kao medicinski, a povezuje ga se također i s provedbom medicinskih intervencija. Uz opći pregled literature vezane uz medikalizaciju trudnoće i poroda, usredotočuje se i na slovenski kontekst. Rasprave o medikalizaciji trudnoće i poroda te fiziološkog poroda ambivalentne su jer tehnološke inovacije pridonose i spašavanju života. Feministička kritika vidi medikalizaciju trudnoće i poroda u funkciji kontrole nad ženskim tijelom i nad reprodukcijom. Proces humanizacije stoga se usredotočuje na ženu i njezinu sposobnost da donosi samostalne odluke tijekom trudnoće i poroda. Pregled literature pokazao je da postoji potreba za daljnjim empirijskim istraživanjima koja bi jasnije objasnila prepletanje tih dviju perspektiva, pogotovo u Sloveniji, gdje je malo takvih istraživanja.

Ključne riječi: medikalizacija, trudnoća, porod, fiziološki porod, feminizam, humanizam 